\title{
KLRK1 wt Allele
}

National Cancer Institute

\section{Source}

National Cancer Institute. KLRK1 wt Allele. NCI Thesaurus. Code C101751.

Human KLRK1 wild-type allele is located within 12p13.2-p12.3 and is approximately $19 \mathrm{~kb}$ in length. This allele, which encodes NKG2-D type II integral membrane protein, is involved in both ligand binding and lymphocyte activation. 